\title{
Labirintos na Cidade Contemporânea
}

Labyrinths in the contemporary city

Edson Luiz André de Sousa $\&$ Janaina Bechler

Universidade Federal do Rio Grande do Sul

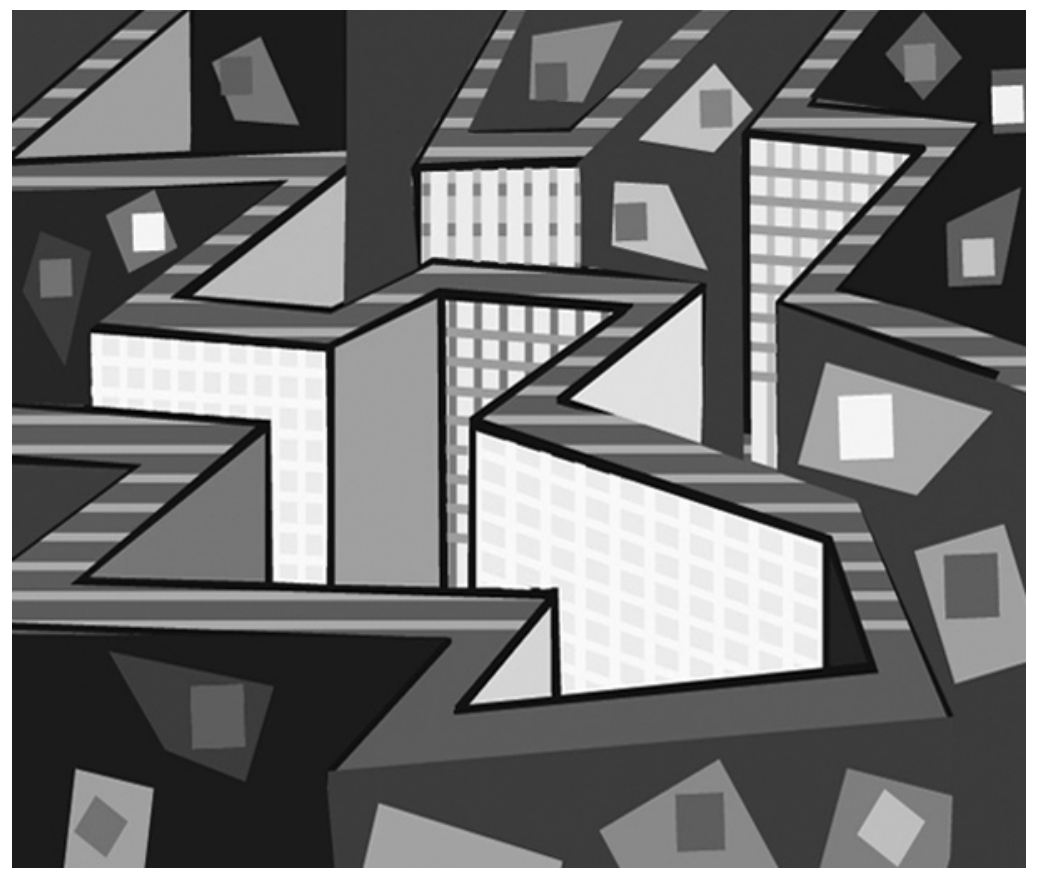


Resumo: Este artigo pretende tensionar pontos de conexão e diluição de fronteiras entre as categorias público/privado, conversando com a literatura de Baudelaire e W. Benjamin, Fredric Jamenson e Marc Augé. Através da imagem do labirinto, símbolo da cidade antiga que se quis extinguir na cidade moderna, busca-se refletir sobre alguns caminhos e caminhantes considerados excedentes na cidade contemporânea. O cenário propulsor dessa reflexão é a experiência do jornal Boca de Rua, elaborado por moradores de rua na cidade de Porto Alegre.

Palavras-chave: Imagem do labirinto. Cidade moderna. Cidade contemporânea. Moradores de rua.

Abstract: This article aims to stimulate tension between the points of connection and dilution within the borders between the public and the private categories, through dialogues held with the works of Charles Baudelaire, Walter Benjamin, Fredric Jameson and Marc Augé. The authors use the image of a maze (a symbol of the old city that was extinguished within the modern city) to propose a reflection on some of the paths and wanderers that are considered leftovers from the older cities. The scenario that motivates this discussion is the experience of the newspaper Boca de Rua, written by street dwellers in Porto Alegre.

Keywords: Image of a maze. Modern city. Contemporaneous city. Street dwellers.

\section{Ponto de partida: jornal boca de rua}

O jornal Boca de Rua redesenhou o horizonte de vida de muitos moradores de rua de Porto Alegre. Trata-se de um jornal trimestral elaborado por moradores de rua com orientação de jornalistas profissionais, além de psicólogos e educadores, que vem sendo publicado desde o ano 2000. Em muitas esquinas da cidade, alguns moradores de rua abrem espaços de visibilidade para suas experiências, assumem o lugar de quem tem algo a dizer sobre a cidade que habitamos. O jornal dá voz ao esquecimento em que se encontram. Outras manchetes abrem espaços nas esquinas da cidade: A rua é $O$ maior estádio, Despejados, Profissões-Perigo, O inverno é o inferno, Drogas, apenas um pedaço da história, Você acredita na cura pela fé?, Faces da noite, Malabarismo da sobrevivência, etc.

Esses moradores nos mostram uma outra cidade pela lente dos seus sofrimentos e da precariedade em que vivem. A palavra escrita no jornal funciona, portanto, como uma espécie de morada onde encontram um lugar de resistência. São muitos os caminhos que esses moradores percorrem. Tais caminhos inspiraram o uso da palavra labirinto neste artigo, como ligação entre a cidade moderna, limpa, aberta, planificada, e a cidade antiga, tortuosa, cheia de curvas e mistérios. Esses habitantes das ruas mostram muitas passagens não planejadas e subvertem os traços ao redesenhar os mapas oficiais. Trazem o labirinto de volta para as grandes avenidas.

Labirinto

Não haverá nunca uma porta. Estás dentro E o alcácer abarca o universo E não tem nem avesso nem reverso Nem externo muro nem secreto centro. Não esperes que o rigor de teu caminho Que teimosamente se bifurca em outro Que obstinadamente se bifurca em outro, Tenha fim. É de ferro teu destino Como teu juiz. Não aguardes a investida Do touro que é um homem e cuja estranha Forma plural dá horror à maranha De interminável pedra entretecida. 


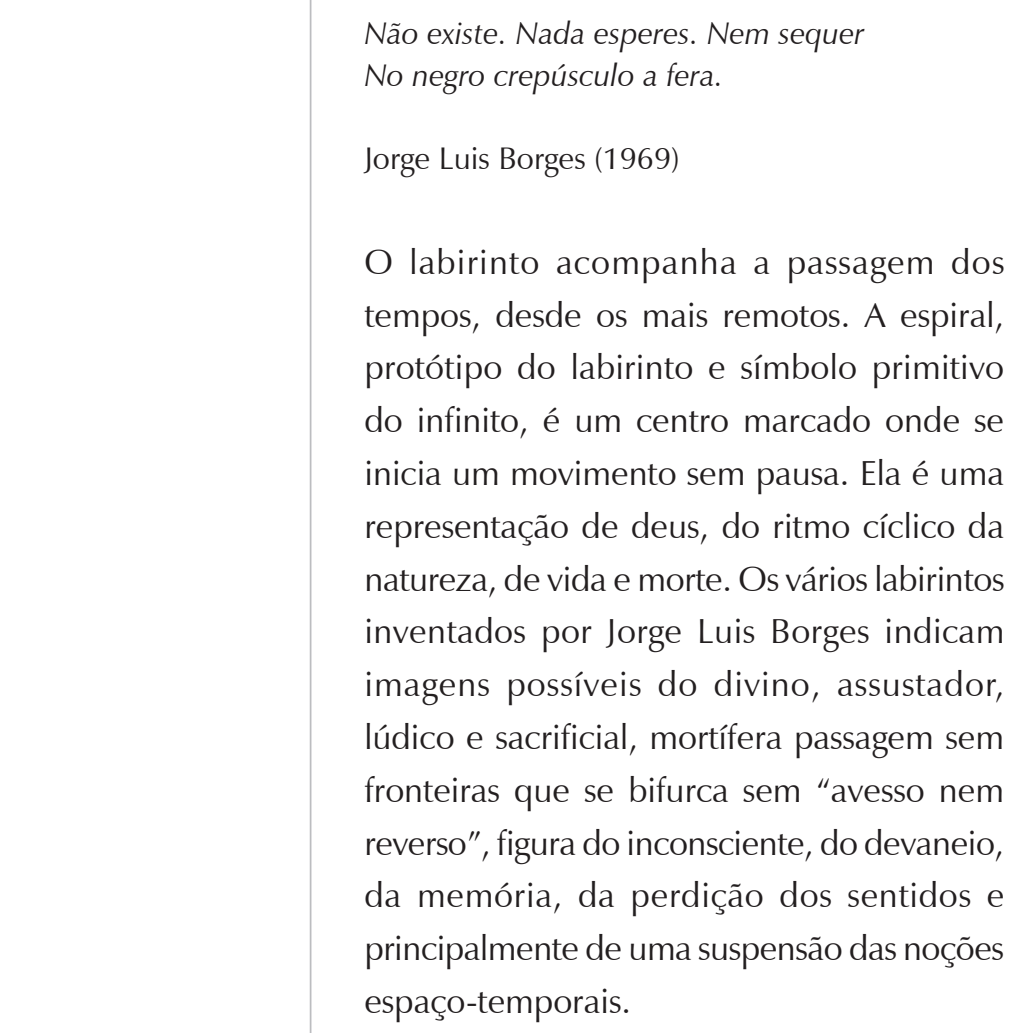

Dos tipos de labirintos descritos por Freitas (1985), a espiral é o único unicursivo. Nela pode-se seguir o percurso até o centro ou retornar à entrada. $\mathrm{O}$ desafio encontra-se nas possíveis portas, provas e monstros encontrados pelo caminho. Os primeiros labirintos urbanos são centrados, hierarquizados como o poder dos monarcas, cobertos de ritualísticas e credos. Com a cruz no centro, reproduzir-se-ão, nos círculos em torno, movimentos cósmicos que espelham estrelas e luas, celebração do uni(verso) antigo. Essa centralização tem a ver com o mote da vida da urb, ou seja, fixar na terra um lugar, encontrar um "centro na terra". A cidade antiga é descrita como verdadeiro labirinto: cercada de muralhas, ruas estreitas e tortuosas, casas com muros sob as ruas, sem janelas, com aberturas voltadas para um pátio interno (Reis, 1994).

Durante o período Minóico, na Ilha de Creta, foi encomendado ao arquiteto Dédalo a construção de um labirinto para encerrar o monstro Minotauro. Essa mescla de homem e touro teria sido enviado pela fúria de Poseidon ao rei Minos, fazendo-o nascer de sua mulher. A cada nove anos, eram sacrificados sete rapazes e sete virgens de Cnossos para satisfazer o monstro. O jovem Teseu, com a ajuda da amante Ariadne, filha do rei Minos, conseguiu atravessar o labirinto desenrolando um fio segurado por ela; por isso, ele tornouse o primeiro herói grego.

Data dessa antiga história a tentativa de extinção da forma labiríntica de cidade. Sua abertura para a visualização do centro foi o ideal perseguido na cidade grega, e, depois do retorno medieval ao labirinto, o racionalismo moderno procurou fazer grandes avenidas, higiênicas, onde tudo se pode ver, enfim, uma cidade à altura dos olhos. O pensamento cartesiano buscava limpar o caminho das formas de contato, poupando sempre o ardiloso e enganador aparelho sensível no acesso ao conhecimento. O desenho forçosamente reto do tempo em linha e do espaço meticulosamente arranjado é produzido nesse pensamento. A espiral centrada, mas circular, cíclica, eterna, nada tem a ver com o pensamento moderno. A progressão temporal na linha reta concebe o progresso e o passado. Tempo-espaço do artifício racional, o moderno quer acender as luzes e diluir as pequenas obscuridades nos cantos dos labirintos.

\section{Caminhos modernos na cidade}

Para Walter Benjamin, a barbárie caracteriza o homem moderno. Esse homem é capaz de inventar, tudo e sempre de novo, porque é pobre em experiência. $\mathrm{O}$ rompimento com a cronologia tradicional, em que a passagem das gerações era determinante na transmissão dos ideais, configuraria uma nova maneira 
de relacionar-se no tempo e no espaço. Se o labirinto assustava tanto o homem renascentista, era porque algumas bases que sustentavam o homem da tradição já vinham se rompendo, e o desconhecido, presente nessa figura, ameaçava a integridade do sujeito que se queria uno.

Newton Bignotto afirma que o homem renascentista foi o primeiro a tornar possível a invenção de uma nova natureza humana. Afirma que os pensadores medievais já sabiam, principalmente Santo Agostinho, que a liberdade de um homem não pode ser limitada por nada que lhe seja exterior. Admitiam, portanto, o poder da vontade em cada ação, mas não acreditavam que o sentido da nossa história pudesse vir de atos particulares. Pensavam que nossas escolhas nos confrontam com uma história cuja significação não depende de nós. O salto do pensamento renascentista é que "criamos com nossas ações o sentido do tempo em que vivemos, e, de maneira geral, o sentido da História". O autor cita uma passagem de Pico della Mirandola que fornece a imagem que os pensadores renascentistas italianos tinham do homem:

Ó Adão, nós não te demos nenhum lugar determinado, nem uma fisionomia própria, nem dons particulares, para que teu lugar, tua fisionomia, teus dons que vieres a desejar, tu os tenhas e os possuas de acordo com teus votos e segundo tua vontade.
Ó Adão, nós não te demos nenhum lugar determinado, nem uma fisionomia própria, nem dons particulares, para que teu lugar, tua fisionomia, teus dons que vieres a desejar, tu os tenhas e os possuas de acordo com teus votos e segundo tua vontade. Para os outros, sua natureza definida é regida por leis que lhes foram prescritas: tu, tu não és limitado por nenhuma barreira, é de tua própria vontade, do poder que te dei, que tu determinas tua natureza. Eu te instalei no meio do mundo, para que examines mais comodamente tudo que nele existe. Nós não te fizemos nem mortal, nem imortal, a fim de que, senhor de ti mesmo e tendo a honra e a tarefa de modelar teu ser, tu te componhas da forma que preferires. Tu poderás degenerar em formas inferiores, que são animais, tu poderás, por decisão de teu espírito, ser regenerado em formas superiores, que são divinas. (Bignotto, 1992)

O poder absoluto de moldar-se de acordo com as escolhas feitas lança o homem ao desconhecido em sua própria casa. É como se o universo das pré-determinações, vinculadas à procedência, ao nome de família e o lugar ocupado por ele na comunidade, vigentes na Antigüidade e ainda existentes na Idade Média, estivesse se rompendo aos poucos, de acordo com alguns fatos importantes da grande História.

A Idade Média, ao mesmo tempo em que representou um tempo de "atraso" em relação ao progresso insinuado pelas civilizações grega e romana, trouxe consigo o primeiro indício de abertura da casa para a rua, integrando o interior à paisagem urbana. A janela, ponto absolutamente importante para pensar o olhar-perspectiva, é uma espécie de recorte de uma abertura também simbólica. Mas, seria realmente de abertura? Ao que parece, a janela surge justamente no momento em que uma história da vida privada se inicia, ao menos tal qual a conhecemos hoje, pois a comunidade, o compartilhamento de valores comuns de forma natural, tácita, como afirma Bauman (2003), passou ser pensada e problematizada na Renascença, desnaturalizando-se. Em outras palavras, o compartilhamento natural já se havia rompido, e a figura do Estado passou a ser presença constante, mediando as relações entre as pessoas na cidade, com tendências a alastrar-se cada vez mais.

Philippe Ariès situa o Estado como um dos grandes fatores significativos para a passagem da comunidade à sociedade. A aparência de um indivíduo passou ser determinante na composição de sua existência social. Para 
tanto, lutava, muitas vezes, com armas para defender a honra, e a imagem se construía muito em função da ostentação de bens materiais. A desigualdade tornava-se gritante. Nesse momento, que o autor localiza desde o século XIII, o Estado passou a mediar a competição dos homens em busca do reconhecimento social, com a proibição de duelos, sob pena de morte, com a revisão dos quadros de nobreza para eliminar usurpadores, e com o início da intervenção na família, que consideramos o âmago do privado (Ariès, 1995).

Outro fato marcante que acarretou mudanças essenciais é o crescente índice de alfabetização e a disseminação da leitura através da imprensa. Isso leva diretamente ao terceiro grande fato, que é a modificação nas formas de religião, a partir dos séculos XVI e XVII. Ambos tendem a trazer o indivíduo para práticas isoladas, solitárias, impensáveis dentro de uma comunidade. A leitura individual, que vinha substituindo aos poucos as rodas de leitura, a transmissão dos textos e a devoção interior, sob forma de exame de consciência, confissão e diários íntimos, incentivados pela religião católica, reduziam um tanto os espaços para o compartilhamento das experiências.

Ariès chama a atenção para uma nova forma de relação com o corpo, fruto dessa condição nova, o estar só, que passa a figurar nessa época. As trocas corporais e a apresentação do corpo que caracterizava a Idade Média passaram a ser repudiadas, dando lugar à distância e ao recobrimento do corpo e de seus dejetos. As demonstrações de afeto como abraço, beijo e jogar-se ao corpo do outro foram substituídos por gestos discretos e furtivos. Esconder a excreção tornou-se uma condição de convivência a partir dessa época.
A literatura autógrafa (os diários, as cartas e todo tipo de registro íntimo) apareceria evidenciando a vontade de conhecer-se através da escrita, sem a necessidade de comunicar o que se escrevia para outras pessoas. Muitas vezes compartilhava-se o conteúdo apenas com os filhos, exigindo que o guardassem na memória e o destruíssem após a morte daquele que o havia escrito.

O gosto pela solidão e a amizade são outras novidades dos costumes. Por muito tempo, o isolamento foi considerado o pior sofrimento, mas, no final do século XVII, começou a aparecer a vontade de estar só, de fazer longas caminhadas acompanhadas da leitura de um livro. Figuras nobres isolavam-se durante horas, para andar, pensar, estar só. A amizade, diferente da fraternidade dos cavaleiros de armas da Idade Média, passou a existir pela escolha, no círculo habitual, de uma pessoa apartada dos outros. Ao amigo é confiada a intimidade, é com quem se compartilha um sentimento mais polido, tranqüilo, de variável intensidade.

O gosto pessoal que se materializará na história da casa de família aparece como um grande valor. A forma de se apresentar, de adornar a casa, são exteriorizações de si mesmo e dos valores que se cultiva. Ariès demonstra que, por muito tempo, as pessoas se limitaram a preencher a casa com móveis e objetos com caráter utilitário e alguns mostradores para exibir objetos preciosos. A preocupação com o conforto e o revestimento artístico desses móveis e, em conseqüência, da forma de viver, é percebido no século XVII. A culinária, bem como a arte de produzir e degustar bons vinhos, passa a exigir certa cultura e espírito crítico, um apreço ao que hoje chamamos gosto.

Todas essas características vão em direção do individualismo de costumes na vida cotidiana, 
Ninguém tem vida privada, mas todos podem ter um papel público, mesmo que seja o de vítima. mas o autor ressalta que isso não significa que a ideologia individualista já existia, como a que vivemos hoje. As mudanças fundamentais da Idade Média para o início de uma sociedade que se chamou Moderna estão na relação, agora com lugares muito definidos, entre os espaços públicos e privados. Mas ela aparece principalmente, comenta Ariès (1995), quando se pensa no papel do Estado:

Na Idade Média, como em muitas sociedades em que o Estado é fraco ou simbólico, a vida de cada particular depende de solidariedades coletivas ou de lideranças que desempenham um papel de protetor. Ninguém tem nada de seu - nem mesmo o próprio corpo - que não esteja ameaçado ocasionalmente e cuja sobrevivência não seja assegurada por um vínculo de dependência. Em tais condições, há confusão entre público e privado. Ninguém tem vida privada, mas todos podem ter um papel público, mesmo que seja o de vítima. Dir-se-á que existe um paralelismo entre essa problemática do Estado e da sociabilidade, pois nas mesmas condições existe a mesma confusão no nível da sociabilidade. (p. 17)

Porém, a divisão do público e do privado, através do Estado de direito, não se dá fácil ou progressivamente. Faz-se, aos poucos e com tropeços, um espaço-tempo para atividades que não têm a ver com a coisa pública: atividades particulares. O autor chama a atenção para uma confusão que freqüentemente se estabelece entre serviço público e público, por conta da proximidade dos termos e das formas institucionais que encontramos no contemporâneo, que dificultam a distinção. Ariès (1995) esclarece:

...existe um segundo aspecto da oposição público/ privado que me escapara, tanto que me tornei estranho às formas políticas da História. Nessa concepção, o público é o Estado, o serviço do Estado, e o privado - ou melhor, como se dizia sem nenhuma ambigüidade, o "particular" - referia-se a tudo que escapasse ao Estado. (p. 25)

Essa distinção é muito difícil de se fazer no contemporâneo. Se, na Idade Média e até o início da época moderna, público se referia aos lugares de convívio, como as praças, os parques, os jardins públicos, na modernidade, essa palavra passou para as mãos do Estado, que administra a cidade, e todos os lugares ditos públicos pertencem a essa instância eleita para representar cada cidadão. O sentido essencialmente comunitário desses espaços aparece com uma roupagem anônima, uma vez que se acha sempre atrelado a essa instância mediadora entre os cidadãos.

Ao mesmo tempo, há, na modernidade, uma privatização cada vez maior do espaço. A industrialização e a conseqüente relação de trabalho assalariado criam espaços de convivência em ambientes privados. Assim como os parques e praças, lugares de convívio, são substituídos ou ao menos concorrem com os cafés, as galerias, lugares de sociabilidade, mas também de consumo. O público se volta cada vez mais para o privado, que parece um lugar público.

É claro que essa nova configuração do espaço tem a ver com o surgimento das sociedades abundantes, em que as pessoas não se conhecem com a mesma facilidade, e por isso não vivem sob o suporte da tradição das famílias. Mas Ariès ressalta o fato de que, no início da modernidade e na Idade Média, ainda havia o interesse festivo por conhecer, estar junto; no contemporâneo, essa tendência tem se apagado em nome do medo do outro, fato que Walter Benjamin localiza muito bem em suas reflexões sobre o início da grande metrópole, Paris, nascente no século XIX . 
A cidade só é possível, do modo como a vivemos hoje, se o corpo e seus dejetos somem dos olhos.

\section{O fenômeno-metrópole}

Anoitecer

É a hora em que o sino toca,

Mas aqui não há sinos;

Há somente buzinas

Sirenes roucas, apitos

Aflitos, pungentes, trágicos,

Uivando escuro segredo;

Desta hora sim, tenho medo.

Carlos Drummond de Andrade

A história do consumo abusivo das drogas coincide com o fenômeno metrópole, com o início da industrialização, com a reprodutibilidade técnica de objetos e obras, acontecimentos que marcaram o século XIX. Uma nova forma de vida surge dessa acumulação. A organização dos espaços públicos tem como principal função dar vazão à multidão que se aglomera nas ruas e, principalmente, dar vida aos locais onde são comercializados os objetos produzidos na indústria. A metrópole, esse universo rico em detalhes, é o lugar possível para essa sintetização do objeto/droga, tão dotado de sentidos diversos.

Em toda síntese - em toda história vencedora -, uma gama de sentidos diversos, de pontos de vista, é deixada de lado. O ponto único de perspectiva adquire um estatuto de poder ao eliminar os enigmas. Assim, a possibilidade de transfiguração de um objeto, de uma cena, de uma paisagem, é obra a ser feita. No universo obscuro da droga, uma cintilância do que é visível cega outros possíveis usos do mesmo objeto. É o corpo drogado a imagem vendida junto com a droga. A imagem que se consome é o resto de corpo que sobra depois do abuso, uma espécie de experimentação dos limites do órgão, do que se desprende do corpo, do que se perde. Mesmo sabendo que esses objetos chamam para a ruína, é para lá que boa parte da juventude volta os olhos.
É que nesse universo - como é chamado o lugar subjetivo no qual ingressa o sujeito que se inicia em alguma droga - o sangue circula, a boca seca, existe o que apodrece. Lá existe esse aspecto tão humano que nos afasta: o corpo e suas vicissitudes.

Uma das formas de se relatar a história da droga é dizer que naquele tempo existia um universo em que o sangue circulava, em que o corpo apodrecia, em que existia a podridão. Se essa história venceu, qual a história que foi denegada? O aspecto anestésico de toda droga é apagado em nome da imagem do corpo drogado, que sempre é mais assustadora. Nesse sentido, essa história da droga, com a dialética entre os extremos de presença do corpo e, ao mesmo tempo, de anestesia, mimetiza o funcionamento da metrópole. A acumulação de corpos circulando nas ruas da cidade é ao mesmo tempo a presença do corpo e a necessidade de sua desaparição. A cidade só é possível, do modo como a vivemos hoje, se o corpo e seus dejetos somem dos olhos.

Não foi à-toa que Baudelaire, e depois dele Walter Benjamin, insistiram tanto na importância do artifício para o homem moderno. A cidade passou a ser "o único campo válido da experiência moderna" (Matos, 1989, p. 72 ). É nesse espaço-corpo de artifícios que se inscrevem as paixões e as emoções do homem da multidão. Esse homem se torna o fluxo da metrópole, de cuja cadência já não é mais consciente. E, "como um véu", olha através dela.

A cidade-metrópole tem um ritmo que se assemelha à lógica aditiva das toxicomanias. Ela é também um sistema de códigos, que se sobrepõem infinitamente e que podemos sintetizar, como a droga. Ela é a imagem do corpo excessivo, que se excede e que é em 
si um excesso, o corpo hiper-estimulado pela presença de outros corpos e dos tantos artifícios feitos para seu conforto e para sua circulação. É um aglomerado de paradoxos, de tensões compartilhadas por quem a habita: é íntimo e coletivo; é tudoao-mesmo-tempo, com tempos diferentes. A cidade é esse tipo de paisagem que não unifica, que não prescinde do ponto de vista, mas que pode, assim mesmo, ser dotada de sentidos estanques, imutáveis para cada um que habita nela, porque a cidade é carne, corpo de quem a habita, tantas em cada uma, condensadas, memoráveis, porque há uma porção de cidades que se delineiam pelos olhares múltiplos que Ihe são lançados.

É uma cidade igual a um sonho: tudo o que pode ser imaginado pode ser sonhado, mas mesmo o mais inesperado dos sonhos é um quebra-cabeça que esconde um desejo, ou então o seu oposto, um medo. As cidades, como os sonhos, são construídas por desejos e medos, ainda que o fio condutor de seu discurso seja secreto, que suas regras sejam absurdas, as suas perspectivas enganosas, e que todas as coisas escondam uma outra coisa (Ítalo Calvino, As cidades invisiveis)

Se, ao olhar um campo aberto, com o horizonte longínquo da união de céu e terra, temos a impressão de que a imagem estava lá antes do olhar, na cidade, o ponto de vista está sempre determinando a imagem. Nesse sentido, ela é, de fato, múltipla, pois há, a cada virada no olhar, uma nova cena sendo montada. Ela é a experiência do evanescente, do novo, do antigo, a cada olhar. É portanto, o espaço e o tempo da modernidade: "A modernidade é o transitório, o efêmero, o contingente, é a metade da arte, sendo a outra metade o eterno e o imutável" (Baudelaire, 1869/1988, p. 175).
Essa maneira de conceber a modernidade, desvinculada de um tempo cronológico preciso, está muito presente na obra de Baudelaire. Para ele, andar nas ruas de Paris do século XIX era viver a experiência do moderno, esse vislumbre do novo-efêmero, já em vias de se tornar caduco; assim percebia que

houve uma modernidade para cada pintor antigo: a maior parte dos belos retratos que nos provêm das épocas passadas está revestida de costumes da própria época...; a indumentária, o penteado e mesmo o gesto, o olhar e o sorriso (cada época tem seu porte, seu olhar e seu sorriso) formam um todo de completa vitalidade. (Baudelaire, 1869/1988, p. 174)

Porém, para ele, o moderno não exclui o antigo. Ao contrário, o moderno cria o antigo ao se estabelecer. Antigo é justamente essa junção de elementos que caracterizam as épocas, que moldam os corpos e as paisagens: "para que toda Modernidade seja digna de tornar-se Antigüidade, é necessário que dela se extraia toda beleza misteriosa que a vida humana involuntariamente the confere" (Baudelaire, 1869/1988, p. 175).

Baudelaire constrói a sua lírica com o véu da multidão frente a seus olhos. Observa algumas figuras que resplandecem na vida moderna, como a prostituta, o flaneur, o jogador, o andarilho, o mendigo. Todos apresentam a nova forma de viver, e, ao mesmo tempo, sua degradação, sua ruína, pois vivem o artifício moderno, sua temporalidade, sua fruição.

O flaneur contempla o mundo e produz alguma resistência com a sua forma de se mover na multidão. Walter Benjamin chama a atenção para o hábito do flaneur de levar tartarugas a passear nas galerias. Essa era a velocidade dos seus passos despreocupados. Não estava jogado no fluxo da multidão, 
A função do poeta, do flaneur, é negativa, trágica, sem esperança, porque não há mais a exigência de síntese, de consolo: o poeta não conseguirá imprimir uma "alma" a essa multidão. mas também não estava fora. Dessa posição marginal, ele tentava atribuir uma alma à multidão. De certa forma, buscava ainda, na contemplação, reconhecer nela o indivíduo, tarefa pouco fácil, já que, na metrópole, “o que está em jogo é justamente a liquefação do indivíduo autônomo, sua dissolução, sua desindividualização" (Matos, 1997, p. 121).

O perfeito flaneur produz uma experiência da multidão. Realiza a transmissão da memória para o papel das imagens da cidade, com toda transfiguração que envolve esse ato. Ele é um apaixonado pela cidade, pela multidão, e é promotor de resistência na massa uniforme na medida em que experiencia e cria imagens críticas à cidade. Seu olhar não encontra o indivíduo na multidão, mas, por seu esforço, negativo, produz ainda um grito:

A função do poeta, do flaneur, é negativa, trágica, sem esperança, porque não há mais a exigência de síntese, de consolo: o poeta não conseguirá imprimir uma "alma" a essa multidão. Baudelaire traduziu tal situação em uma imagem deslumbrante, quando fala que se trata de um duelo do qual o artista sai vencido, mas antes há um grito. (Matos, 1997, p. 121)

Baudelaire (1869/1988) refere-se ao dândi, figura contemporânea ao flaneur, como alguém que vive a multidão de forma entediada. Esse olhar talvez fosse o predominante, pois a multidão acabará por mimetizar a fábrica taylorista, que poderíamos nomear como "máquina de ignorar o real" (Rosset, 1999, p. 57). O funcionamento da máquina estará impresso no corpo humano, que, fragmentado na linha de produção, sairá às ruas da cidade:

Se, em Poe, os passantes lançam olhares ainda aparentemente despropositados em todas as direções, os pedestres modernos são obrigados a fazê-lo para se orientar pelos sinais de trânsito. A técnica submeteu, assim, o sistema sensorial a um treinamento de natureza complexa. (Benjamin, 1939/1989, p. 124)

O homem comum é entediado, completamente dentro do fluxo da multidão da metrópole. Tanto essa forma de andar quanto aquela forma de trabalhar remetem à despersonalização das relações sociais. $\mathrm{O}$ olhar conduzido pela convenção de sinais do transeunte e a ausência de correspondência entre um gesto e outro do trabalhador na fábrica são espelhos de uma certa relação entre a memória, a história, e a transmissão, que nasceram com a metrópole, fenômeno do capitalismo.

A multidão metropolitana, segundo Benjamin, despertava medo, repugnância e horror naqueles que a viam pela primeira vez. $\mathrm{O}$ flaneur vivia também uma experiência de choque a cada vez que entrava na multidão: era como entrar em um reservatório de eletricidade. O que acontece ao homem comum que anda na multidão entediado? Será que deixou de sentir toda a eletricidade do encontro entre os corpos, dos choques de olhares, dos estímulos dos sinais de trânsito, das luzes acesas? Que mecanismos fazem com que o corpo transite entediado, incólume, na multidão?

A experiência do choque é o cotidiano do homem moderno. Uma certa anestesia, pelo hiper-estímulo, é um dos componentes do olhar entediado do dândi na multidão. De alguma forma, a sensibilidade adequou-se ao excesso:

É evidente que o olho do habitante das metrópoles está sobrecarregado com funções de segurança. Simmel faz referência a outro aspecto desgastante, porém menos evidente. Quem vê sem ouvir, é muito mais... inquieto do que quem ouve sem ver. Eis aí algo característico da...grande cidade. As relações recíprocas dos homens 
nas grandes cidades...distinguem-se por uma preponderância notável da atividade da visão sobre a audição. (Benjamin, 1939/1989, p. 142)

Essa vivência do choque na metrópole traz consigo uma nova noção de tempo. É o instantâneo colocado em cena. O descontínuo passo na multidão, o gesto fabril eternamente reiniciado, são fragmentos de tempo que não mantêm entre si correspondência necessária. Também os olhares na multidão produzem o tempo recortado, descontínuo.

Na cidade contemporânea, a captura do cotidiano e da rua

A rua, o único campo válido da experiência Breton

Na contramão da cidade moderna, o labirinto parece explodir em muitos. Em cada avenida, uma torção, e, a cada beco desfeito, outros tantos traçados. A cidade contemporânea é um emaranhado de labirintos multiformes e multicentrados, pois ela é o território daquele que deriva sem-lugar: "o labirinto é a pátria de quem hesita. O itinerário daquele que teme chegar ao fim desenhará facilmente um labirinto" (Benjamin, 1939/1989, p. 162).

Os citadinos, como portadores de garrasgrafitis, desenham labirintos tortuosos no gesto de caminhar. Devolvem então à cidade, em seus percursos erráticos, a história labiríntica que foi subtraída pelo progresso.

Fredric Jameson afirma que, no pósmoderno, o tempo de alguma forma se tornou espaço. Chama-nos a atenção para a ligação da memória com o espaço na obra de Proust, no qual a lembrança acontece involuntariamente, obedecendo a uma certa lógica de arranjos entre o espaço subjetivo e o material. É como se os objetos do interior da casa, nos lugares públicos que freqüentamos, dissessem de nossa vida subjetiva, arranjando formas de viver.

Há uma dificuldade em limitar a abrangência do espaço "exterior" em relação ao "interior", uma vez que essas categorias existem somente na relação entre um e outro. São, de certa maneira, indissociáveis. No contemporâneo, no entanto, essa relação encontra-se posta à prova, pois, ao que parece, há uma invasão do "exterior", daquilo que não faz parte dos ideais familiares ou comunitários, mas que acaba moldando subjetividades.

Nesse contexto, onde as fronteiras estão relativizadas, observa-se um fenômeno paradoxal: de um lado, afirma-se a necessidade de maior abertura para a diversidade cultural, para o outro, para a diferença; de outro, há um fechamento gradativo das fronteiras, o estrangeiro é encarado como figura ameaçadora, terrificante, e a negação da diferença se dá na mesma proporção que a afirmação de sua necessidade.

Através das tecnologias informacionais, o cotidiano da vida privada tornou-se objeto de imagificação e culturalização. Uma literatura chamada "realismo sujo", originada nos Estados Unidos, durante os anos 90, é analisada por Jameson como espelho da modificação da noção de espaço em nosso tempo e da passagem do cotidiano para o plano da cultura. Situa-se em um campo aberto no modernismo, principalmente com a pop art, que já soube transformar o cotidiano em espetáculo e mesclou categorias de arte que não andavam juntas. Cultura de massa e cultura das elites tornaram-se de tal forma imbricadas que a discussão sobre o que pode ser considerado cultura se tornou muito mais 
O estilo clean, que caracterizou os anos 90 e ainda predomina nas modas em geral, é a negação do aposento burguês do século XIX, que Benjamin descreve com minúcias, em que cada detalhe lembra aqueles que o habitam. complexa.. Dizia o autor sobre o realismo sujo:

São histórias estranhas, sem enfeites, sem mobiliário, tragédias baratas sobre pessoas que assistem à programação diurna da televisão, lêem romances baratos ou escutam música country e western. ...Eles jogam bingo, comem cheesburgers, caçam veados e se hospedam em hotéis vagabundos. ...vagam por um mundo cheio de junk food e dos detalhes opressivos do consumismo moderno. (Jameson, 1997, p. 151)

Diferente dos movimentos da arte que buscam uma transfiguração da vida-arte, opera-se uma apreensão da vida e da arte por um modelo de circulação social baseado na lógica do consumo. Jameson interessa-se por essa manifestação cultural pelo contexto em que se insere e principalmente por ser uma tentativa hiper-realista de representar o cotidiano. Chega a questionar se, em nossa época, a sensação da "vida real" não teria passado para o plano da ideologia. Uma vez que se vive a imersão no mundo de virtualidades, onde a tecnologia veloz impõe certas condições à realidade dos acontecimentos, como desenvolve Virilio (2002), perceber o que é a "vida real" tornou-se uma busca que se faz de diversas maneiras.

Os programadores televisivos já descobriram que essa é uma vontade coletiva e povoaram canais com "reality shows". A internet está repleta de espaços reservados à apresentação da vida cotidiana de pessoas anônimas, que instalam em suas casas câmeras de vídeo que transmitem o cotidiano ao vivo. Ambos os entretenimentos só fazem sentido se há uma ausência de representação para as ações mais cotidianas, e instala-se a necessidade de buscar modelos, inclusive para andar do quarto até a cozinha, escovar os dentes, comer macarrão, dormir, acordar, o voyeurismo expandido a preencher as horas de tédio dos habitantes cegos e sem imagens que o representam na vida das metrópoles.

A vida de contemplação passiva, que faz a diferença radical daquele flaneur descrito por Baudelaire, acontece em outra conformação de espaço. O estilo clean, que caracterizou os anos 90 e ainda predomina nas modas em geral, é a negação do aposento burguês do século XIX, que Benjamin descreve com minúcias, em que cada detalhe lembra aqueles que o habitam. É também a negação das massas nas ruas e sua sujeira inevitável. Os personagens do realismo sujo freqüentam ambientes nada característicos, que poderiam ser qualquer lugar, sem mobília, sem enfeites:

Temos que pensar o espaço do realismo sujo como um espaço coletivo construído, no qual a oposição entre interno e externo é anulada. ...A fantasia do realismo sujo reforça fortemente a maneira como, em partes de Tóquio, a rua é, de certa forma, interna, de maneira que a cidade como um todo, sem perfil, se torna um imenso continente amorfo irrepresentável. (Jameson, 1997, pp. 160-161)

Esses lugares ascéticos podem ser vistos como aqueles grandes complexos- totalidades de consumo, onde se pode comprar roupas, alimentos, ir ao teatro, ao cinema, passear, fazer tudo o que antes se fazia na rua. São lugares que derivam dos antigos mercados ao ar livre, mas com a economia da sujeira das ruas e do encontro com a multidão de pessoas. Eles são públicos, ao mesmo tempo em que privados. Que fazer com essas categorias, questiona Jameson, no contemporâneo, diante da desaparição de suas fronteiras?

O que toma agora lugar da oposição entre público e privado? Existe alguma zona intermediária entre os dois que sobrevive e como se pode teorizar hoje a vida diária ou cotidiana da rua, como uma candidata a 
ocupar essa posição intermediária? Acredito que seja produtivo pensar o novo espaço em termos de terra de ninguém, não no sentido de uma guerra propriamente dita, mas no de todas as formas tradicionais anteriores de fronteiras (o paradoxo aí é que a categoria de fronteira desapareceu nessa situação). Espacialmente, isso pode ser imaginado como um lugar onde nem a propriedade privada nem a lei pública existem. (Jameson, 1997, p. 163)

O autor propõe novas maneiras de considerar a clássica oposição entre o domínio do público e o da família, que é sempre uma representação do privado:

Esses novos espaços são o espaço do trabalho (aparentemente público, mas possuído por indivíduos particulares) e o espaço da rua, doravante chamado vida diária ou cotidiano, que é tanto um signo de rompimento do privado e do pessoal quanto da emergência do consumo e da mercantilização em oposição ao próprio espaço público. (Jameson, 1997, p. 159)

\section{O lado de dentro do lado de fora no ato de morar}

A evidência de que as fronteiras entre público e privado foram quebradas está nas ruas da cidade. O encurtamento de áreas públicas para utilização da propriedade privada se fez natural, e é justificado em nome de benefícios aos cidadãos. Um quiosque que vende sorvetes dentro de um parque é admitido, pois traz bem-estar ao cidadão que passeia, além de pagar imposto à prefeitura. Ocupando uma área muitas vezes menor que o quiosque, uma pessoa que queira ou necessite pernoitar em um parque da cidade será advertida por infringir o estatuto dos parques, que determina que nada pode lá permanecer para garantir a área pública. Um contra-senso absolutamente naturalizado se abre diariamente à percepção de quem caminha pela cidade.

Ao lado do outdoor de uma grande empresa de telefonia, o olho captura, pela janela do ônibus, um varal estendido na margem do monumento. Sem paredes, o varal atualiza a ventilacão público/privado. Ele é fixo e poroso, parede e abertura. Ele não concebe dentro ou fora, impõe-se com a mesma grandeza do luminoso anúncio, esse fixo, mas move-se acompanhando o olhar. Lado de dentro, de fora, sem paredes e abrigo.

Quem mora na rua atualiza a pergunta diariamente através de sua forma de circulação. Carrega consigo as coisas que lhe pertencem e cata, geralmente na lixeira alheia, o que Ihe falta, um ato de transbordamento do público e do privado que está contido em um gesto diário, banal. São atualizações de formas de vida antigas, quase esquecidas, dos povos nômades e dos viajantes. Interrompem o tráfego carregando suas montanhas de papel, atiram o corpo na calçada, grudando pele e concreto até não descolar. Fazem-se montanhas quando se cobrem de cobertor cinza como a laje. Extensões do caminho, interrompem quando o corpo já não responde. Paralisam e dormem com o sinal de trânsito colorindo sua face: vermelho, verde, amarela. Iluminação cênica-natural-artificial da cidade, pinta os corpos jogados no asfalto. Cena da rua de qualquer metrópole, segundo ato: deslocamento, tropeço de percepção. O deslocamento é da origem do sentido. O movimento contínuo de deslocamento pode não calcificar o sentido; despossuído, aberto ao céu, junto da pedra/terra, corpofica e move o sentido da cidade.

Mais uma vez, o varal estendido ao lado do viaduto revolve conceitos. Augé (1992) 
trabalha o conceito de não-lugar a partir da caracterização feita por Michel de Certeau de "lugar":

Finalmente, o lugar é necessariamente histórico a partir do momento em que, conjugando identidade e relação, ele se define por uma estabilidade mínima, por isso é aqueles que nele vivem podem aí reconhecer marcos que não têm que ser objetos de conhecimento. O lugar antropológico, para eles, é histórico na exata proporção em que escapa à história como ciência. Esse lugar que os antepassados construíram..., que os mortos recentes povoam de signos, que é preciso saber conjurar para interpretar, cujos poderes tutelares um calendário ritual preciso desperta e reativa os intervalos regulares. (Augé, 1992, p. 52)

O "lugar" é permeado de sentidos próprios que não se resumem ao espaço físico, mas o englobam, de tal maneira que ele acaba habitando quem mantém relação com ele. $\mathrm{O}$ autor menciona as tradições em que o "lugar" de nascimento é determinante do nome próprio: o lugar do nascimento é constitutivo da identidade individual e acontece, na África, de crianças nascida por acidente fora da aldeia receberem um nome particular emprestado de um elemento da paisagem que a viu nascer. (Augé, 1992, p. 52)

Essa questão dá luz à difícil conexão apresentada na expressão "Meu nome é Luis, sou morador de rua": nomenclatura ampliada que é possível de se ouvir em um espaçotempo instável, onde a terra já não remete à origem e "lugar" não se vincula facilmente a identidade. A expressão designa rua como um traço identificatório. Rua pode ser um "lugar"? A pergunta traz novamente a linha difusa dos conceitos de público e privado.

Augé (1992) utiliza a expressão não-lugares para todos os espaços que não se podem definir como identitários, relacionais ou históricos. São aqueles produzidos pelo que chama de supermodernidade, que se distanciam do lugar antropológico e também do lugar antigo sugerido pela leitura da modernidade baudelairiana. São espaços como os descritos por Jameson, clean, que preconizam a ausência de uma proposta relação habitável. Entre eles, estão as vias de trânsito, estações de metrô, rodoviárias e aeroportos, redes de hotéis (e todas as ocupações territoriais provisórias, luxuosas e as muito pobres). São espaços para a solidão, para o indivíduo, para o efêmero e provisório.

Como passagem, a rua é o provisório, lugar do encontro fortuito. Mas também é do acontecimento possível. Condenada à primeira possibilidade pelas políticas públicas governamentais, que voltam todos os esforços para uma limpeza relacional das calçadas, tem alguns momentos de transfiguração quando, na contra-corrente, é presenteada com um varal.

No espaço insinuado entre as peças de roupas que se agitam no cenário urbano, forma-se o labirinto (figura que não se duplica, mas é multiforme) e enlaça público e privado em seu gesto de voar; o entre que abre a porta dos mocós e acende lâmpadas no alpendre, deita e sonha, casa-rua ("rua ladrilhada", como a canção infantil). A brecha de espaço entre público-privado pode ser buscada nesse gesto de voar, no gesto de caminhar guiado por mapas estrangeiros dos situacionistas, na arte de perambular, de andar de charrete em 2006, ter uma casa-caracol, no detalhe, no traço, na linha difusa e na encruzilhada onde são deixadas oferendas e escolhas.

Que podemos ainda aprender com a experiência desses sujeitos que habitam as 
ruas de nossas cidades contemporâneas? Milton Santos aposta que a carência em que vivem pode abrir, na consciência de nosso tempo, "formas inéditas de trabalho e de luta" (Santos, 2000, p. 132). Precisamos, portanto, ter o tempo de um contato e de uma escuta para que possamos esboçar minimamente o desenho de um novo tempo. Nesse novo cenário, que ainda sonhamos, seguiremos a pista deixada por Maiakovsky (1917/1997)

"As ruas serão nossos pincéis, as praças nossas paletas.

\section{Edson Luiz André de Sousa}

Psicanalista; professor do PPG Psicologia Social e Institucional e do Departamento de Psicanálise e Psicopatologia do Instituto de Psicologia da UFRGS; professor do PPG Artes Visuais do Instituto de Artes da UFRGS; Doutor em psicanálise e psicopatologia pela Universidade de Paris VII. Pesquisador do CNPQ.

E-mail: edsonlasousa@uol.com.br

\section{Janaina Bechler}

Psicóloga; Mestre em Psicologia Social e Institucional pela UFRGS; professora da Universidade Regional Integrada - Campus Santo Ângelo.

E-mail: janainabechler@gmail.com

Endereço para correspondência:

Universidade Federal do Rio Grande do Sul, Instituto de Psicologia, PPG Psicologia Social e Institucional, Rua

Ramiro Barcelos, 2600 SI.13 - Térreo

Santana. 90035-003 - Porto Alegre - RS.

Recebido 03/05/2007 Reformulado 17/12/2007 Aprovado 28/03/2008

Ariès, P. (1995). Por uma história da vida privada. In P. Ariès \& R. Chartier (Eds.), História da vida privada - Da Renascença ao século das luzes (Vol. 3). São Paulo: Companhia das Letras.

Augè, M. (1992). Não-lugares: uma introdução a uma Antropologia da supermodernidade. Campinas, SP: Papirus.

Baudelaire, C. (1988). O pintor da vida moderna. In C. Baudelaire, A modernidade de Baudelaire. Rio de Janeiro: Paz e terra. (Trabalho original publicado em 1869)

Baumann, Z. (2003). Comunidade - A busca por segurança no mundo atual. Rio de Janeiro: Jorge Zahar.

Benjamin, W. (1989). Charles Baudelaire: um lírico no auge do capitalismo. In W. Benjamin, Obras escolhidas III. São Paulo: Brasiliense.

Benjamin, W. (1989). Parque central. In W. Benjamin, Obras escolhidas III. São Paulo: Brasiliense. (Trabalho original publicado em 1939)

Bignotto, N. (1992). O círculo e a linha. In A. Novaes (Org.), Tempo e história. São Paulo: Companhia das Letras.

Borges, J. L. (1969). O Labirinto. In História universal da infâmia \& outras histórias. São Paulo: Círculo do Livro.
Freitas, L. (1985). Das geometrias labirínticas. Revista ICALP, Lisboa, 2/3, 69-81.

Jameson, F. (1997). As sementes do tempo. São Paulo: Ática.

Maiakovsky, V. (1997). Poemas. São Paulo: Perspectiva. (Trabalho original publicado em 1917)

Matos, O. C. F. (1989). Os arcanos do inteiramente outro - A Escola de Frankfurt. A melancolia e a revolução. São Paulo: Brasiliense.

Matos, O. C. F. (1997). História viajante: notações filosóficas. São Paulo: Nobel.

Reis, N. G. F. (1994). A perspectiva do arquiteto sobre a cidade. In Olhares sobre a cidade. Rio de Janeiro: Ed. UFRJ.

Rosset, C. (1999). O real e seu duplo. Porto Alegre: LPM.

Santos, M. (2000). Por uma outra globalização - Do pensamento único à consciência universal. Rio de Janeiro: Record.

Virilio, P. (2002, junho). "Sejamos resistentes". Revista República, p. 95-105. 